\title{
Editorial Introduction
}

\author{
Lynette Shultz \\ University of Alberta \\ 1shultz@ualberta.ca \\ "There comes a time when silence becomes dishonesty" \\ Franz Fanon, 1969
}

This special issue of the Journal of Cultural and Pedagogical Inquiry focuses on pedagogical acts that might serve to understand, contest, and/or shape the Israel Palestine conflict as it moves, hopefully, toward more just and peaceful relations. Surely this means the liberation of the Palestinian people from the occupation of their land, which includes occupation of their bodies; their communities; and indeed their futures. Gilligan and Richards (2009) in their recent book, The Deepening Darkness: Patriarchy, Resistance, and Democracy's Future", describe the "paradox of intolerance" where an idea or a tradition that originally served one social purpose, can, over time and through changing circumstances, lose its reasonable foundation. At this point, it will stagnate and depend increasingly on appeals to orthodox conceptions of truth and violent repression of any dissent. In fact, dissent becomes a kind of disloyal moral treason (p. 129). In the Israel-Palestine conflict, such a paradox seems at the foundation of international responses to the escalations of violence and the resistance toward any peaceful resolutions of the situation. As Grayston and Chang (this issue) describe, it is time that people in the West name and end the "interfaith, intercultural deal" where refraining from criticism of the State of Israel was exchanged for refraining from criticism of Christians for their complicity in the WWII Holocaust (ibid). This "deal" has become embedded in the Canadian social and political systems where attempts to bring justice to Palestinians is met with immediate social and political closure. Naming and understanding this "deal" is also significant in that it reveals who has traditionally been part of the discussion. When the deal is between Christian and Jew; between Canadian government and Israeli government, where is the voice of Palestinians? Where is the Arab and/or Muslim voice? Edward Said in his work on Representations of the Intellectual(1994), and many subsequent writings, described the difficulty of an Arab speaking out against USA or Israel policy. It is "so inflamed a situation, the hardest thing to do as an intellectual is to be critical, to refuse to adopt a rhetorical style" (p. 118) but "on the other hand, there is a virtual certainty of getting an audience if as an Arab intellectual you....attack the officially approved enemies [of the US and Israel]" (p. 118). We seem at a historical moment where this might be shifting. Where then, are the points of transformation for peace? Are there any points where liberation might be able to emerge?

As critical educators, we have come to understand that the relationship between oppressor and oppressed must be liberated in its entirety if there is to be any liberation at all. Here the foundation of critical pedagogy can be called upon to situate the needed action. In Pedagogy of the Oppressed, Freire addressed the problem of human liberation and the struggle for solidarity with the oppressed:

Cultural and Pedagogical Inquiry, 2010, 2 (2), Special Issue, pp.1-4

ISSN 1916-3460 @ 2011 University of Alberta

http://ejournals.library.ualberta.ca/index.php/cpi/index 
Discovering himself to be an oppressor may cause considerable anguish, but it does not necessarily lead to solidarity with the oppressed.... If what characterizes the oppressed is their subordination to the consciousness of the master..., true solidarity with the oppressed means fighting at their side to transform the objective reality which had made them these 'beings for another'. (Freire, 2000, p. 34).

\section{What are critical pedagogical acts that might be part of such liberation?}

Given the length and intensity of the conflict, we might well imagine that things should be improving (as educators we work with the ongoing commitment that learning and change are possible), but as Gilbert Achcar (2009) suggests, we can understand the resistance to change by acknowledging "that Israel is the only European colonial settler state in which the political rights of the native populations have yet to be restored" ( $p$. 26). Resistance to resolving the conflict (both internationally and domestically) can be, at least partially, founded on particular elites' desire and longing for the retention of colonialism with its "dependable" raced, gendered, and classed hierarchies (Shultz, forthcoming). However, in order to address the current realities in Palestine, we can draw on the many successful anti-colonial movements to overturn these hierarchies. Such struggles have produced many positive changes (although, by no way should we view colonialism as being a project "of the past" in any location). Current calls to action for Palestinian solidarity have coalesced around the idea that addressing the Israel-Palestine context as a colonial system of apartheid provides both accuracy and urgency to guide the gathering and (in many places) intensifying social movement for liberation of the Palestinian people. Actions such as the current boycott and divestment campaigns, similar to those used to educate about South African apartheid as well as to engage the world in an act of resistance that had a large impact on bringing about the end of that colonial injustice, are currently gaining traction in communities and on university campuses in many parts of the world.

The articles in this journal are from Canadian academics from different intellectual locations and disciplines, and who come to the Israel-Palestine conflict with different views. This provides a rich and textured examination of the conflict, its history, and the pedagogical possibilities (and imperatives) that might lead toward peace. To date, this longstanding conflict has proved to be problematic for Canadian educators who attempt to teach its historical, cultural, or political aspects. The conflict is complicated by the wider social and political responses to both the September 11, 2001 events in the United States, and the "war on terror" that followed, thereby creating even more entrenched and essentialized identities of "Muslim" and "non-Muslim", "Arab" and "non-Arab", and pitting citizen against citizen in pluralistic societies such as Canada. As in most conflicts, getting the full range of perspectives and uncensored information proves to be difficult. In Canada, educators have been sanctioned and silenced when they have attempted to organize speakers or events that engage anything but the most superficial understandings of the conflict. What then should educators do? Are educators 
obligated to teach about and within conflict in general and the Israel-Palestinian conflict in particular? What should be known about the conflict? What is the role of outsiders in finding solutions to national conflict? What theoretical and conceptual frameworks provide platforms for engaging in conflict transformation, peacebuilding, and justice?

In response to the closing of pedagogical spaces where anti-oppression, anti-colonial, and pro-Palestinian perspectives are presented, Len Findlay, University of Saskatchewan, in this issue, calls for the full engagement of academic and artistic freedom to provide educational space to practice a "pedagogy of the suppressed". He provides examples of the suppression of artistic freedom and how this can shed light on how the IsraelPalestine conflict might be viewed to create the change in the Canadian political climate that is "so officially pro-Israel" (Findlay, this issue).

Donald Grayston (Simon Fraser University) and Dave Chang (University of British Columbia) frame the pedagogical challenges of the Israel-Palestine conflict through a case study where a British Columbia secondary school exam question that presented a Palestinian perspective was removed from the provincial test bank when Zionist lobby groups objected. Grayston and Chang provide a historical, political, religious, geopolitical and emotional analysis of the context that makes such an act both possible and highly problematic. They end their article with recommendations for peace education that resists the kind of reliance on the seductive comforts of intolerance that Gilligan and Richards describe as so destructive to peace, justice, and democracy.

Penni Stewart (York University) presents the lessons learned from events at York University in Toronto, Canada, where faculty and students engaged in education activities that challenged an exclusively pro-Israel perceptive on Palestine-Israel relations. Even when these activities were meant to open educational spaces where contested ideas might be engaged, the spaces were closed before such engagement could take place. The article presents these events, subsequent reports and inquiries into the activities of faculty and administrators, and the range of political actors and interests involved,through a lens of the corporatization / commercialization of the academy. From this perspective, we can see that how education on critical justice issues such as Palestinian liberation have become a problem of the market to administrators. If what is needed to support acts of justice that might lead or support liberation and peace is new spaces of both inquiry and engagement, the closing of these very places for reasons of marketization seem outrageous. Stewart asks us to ponder the extent that universities will engage go to protect their corporate image in these times that so desperately need new relations and ideas for justice; ideas that might be born within academic environments where rigorous and critical inquiry is nurtured.

The final article comes from Evelyn Hamdon (University of Alberta) and community activist Scott Harris. These student/activists present their experiences and analysis of organizing "Israeli-Apartheid Week" (IAW) in collaboration with student groups across Canada. This pedagogical event is immensely unpopular with political figures in and near the political power centres (both geographically and ideologically) in Canada. Hamdon and Harris argue that the key mechanism these powerful actors use to limit this annual 
event is to close down the space before it becomes a critical pedagogical space. The authors help us to understand why IAW is perceived as so dangerous and how efforts to silence this form of popular education emerged mainly from non-academic, nonuniversity actors. These efforts seem to have been relatively unsuccessful as the IAW network continues to expand across the country and activists find new ways to engage and challenge the imposed barriers and restrictions on their gatherings.

\section{Conclusion}

The beginnings of this special issue came from a collaborative educational project that engaged graduate students in reflections on the life and activism of Rachel Corrie, a young American who was killed in 2003 by an Israeli army bulldozer while protesting the demolition of Palestinian homes. The students' commitments to action led to further involvement with peace initiatives and education gatherings to sort through information that was being presented by North American media during the bombing of Gaza in January 2009. Then, at a conference at the University of Glasgow, I encountered the intellectual and political activist, Keith Hammond, whose work is an exceptional example of critical pedagogy in Higher Education that stands in authentic solidarity with Palestinian people. His constant reminder to stay focused on the daily experiences of oppression that Palestinian people encounter provides the wisdom needed for any educator hoping to contribute toward Palestinian justice. My hope is that the gathering of these contributions will provide a pedagogical tool to help educators enter, continue, and/or extend their critical inquiry into the Israel-Palestinian situation and to also find solidarity and, perhaps even some courage to become part of the deep liberation that needs to be accomplished.

Achcar, G. (2009). The Arabs and the Holocaust: The Arab-Israeli war of narratives. New York: Metropolitan Books.

Freire, P. (2000). Pedagogy of the oppressed. New York: Continuum.

Gilligan, C., Richards, D. (2009). The deepening darkness: Patriarchy, resistance and democracy's future. New York: Cambridge University Press.

Said, E. (1994). Representations of the intellectual. New York: Vintage Books.

Shultz, L. (forthcoming). Decolonizing social justice education: From policy knowledge to citizenship action. In Abdi \& Guo (Eds). Decolonizing Education Philosophies. Rotterdam: Sense Publications. 